\title{
Contagion and Cultural Perceptions of Accepted Behaviour Tuberculosis and Venereal Diseases in Scandinavia c.1900-c.1950
}

\author{
Ida Blom
}

$\mathrm{D}$ uring the nineteenth and early twentieth centuries, industrialisation and urbanisation created densely populated areas, surroundings that facilitated the spread of contagious diseases. Simultaneously the growth of democracy paved the way for legislation to assist the needy without hurting their dignity. As social hierarchies weakened, so did the use of demeaning poor law institutions. Demand for social and political equality resulted in a growing system of social legislation that later developed into the modern welfare state. All this heightened respect for the individual citizen.

From the middle of the nineteenth century, public initiatives such as constructing sewage systems and assuring a supply of clean water aimed at safeguarding the population against disease. The advent of bacteriology during the final decades of the nineteenth century opened new ways of minimising contagion. Individual citizens were admonished to comply with certain rules of behaviour and political authorities were faced with the question of how far they should be allowed to intervene in private lives in order to protect society against contagion. To what extent should an individual be able to freely decide how to tackle contagious diseases such as tuberculosis or syphilis? What could and should be done to protect society against people who suffered from these diseases?

This paper investigates how cultural perceptions of accepted behaviour influenced preventive strategies in the fights against tuberculosis (TB) and venereal diseases (VD). I attempt to compare legislation adopted by Scandinavian parliaments between the end of the nineteenth century and until the middle of the twentieth century. The question to be considered is whether members of parliaments blamed certain behaviours for bringing disease and how the acceptability of such behaviours influenced measures to prevent contagion. I shall not discuss how the general public reacted to the laws or how the laws were practised. 
Given the very similar social and political systems of the three Scandinavian countries it should not come as a surprise that they by and large solved the problem in rather similar ways. ${ }^{1}$ But as this paper shows, some differences may be observed and I shall offer possible explanations for these differences.

\section{Scandinavian Legislation against Tuberculosis}

As the first of the Scandinavian countries, Norway, in 1900, passed a law to promote the fight against TB. The Danish parliament in 1897 included TB in the existing law on contagious diseases and in 1905 passed two laws particularly concerning TB. Small revisions in 1912 did not change the main characteristics of the Danish laws. Sweden legislated on TB in 1914 with important revisions in 1939. Like in many other parts of the world, also in Scandinavia bacteriology strengthened the perception that certain behaviours heightened the chances of infection: squalid living conditions, poor standards of nourishment, spitting, lack of fresh air. The image of the tubercular shifted from the pale genius of former times to the urban poor. The fact that TB was conspicuously more frequent with poor families confirmed such understandings and coloured legislation to combat the disease. ${ }^{2}$

The Norwegian law of 1900 was understood as '... a law for the healthy, ... to protect as many as possible of the individuals in society against contagion.' ${ }^{3}$ Legislation aimed to control the spread of disease from the infected to the rest of

1 Gösta.Esping-Anderson, The Three Worlds of Welfare Capitalism (Cambridge, 1990). Peter Baldwin, The politics of social solidarity: class bases of the European welfare state 1875-1975 (Cambridge, 1990). Niels Finn Christiansen and Klaus Petersen, "Norden som folkehjem", in Edgeir Benum et al., eds. Den mangfoldige velferden. Festskrift til Anne-Lise Seip (Oslo, 2003), pp.13-25. Niels Finn Christiansen, Niels Edling and Klaus Petersen, eds., The Nordic Welfare State - a Historical Re-appraisal. (Copenhagen 2006).

2 Katherine Ott, Fevered Lives. Tuberculosis in American Culture since 1870 (Cambridge Massachusetts, 1996). Linda Bryder, Below the Magic Mountain. A Social History of Tuberculosis in Twentieth-Century Britain (Oxford, 1988). Barbara Bates, Bargaining for Life. A Social History of Tuberculosis, 1876-1938 (Philadelphia, 1992). Mark Harrison, Disease and the Modern World 1500 to the Present Day. (Cambridge, 2004), pp. 124-128. Ida Blom, "Bilder og budskap - tæring og tuberkulose" in Kari Tove Elvbakken and Per Solvang, eds., Helsebilder. Sunnhet og sykdom $i$ kulturelt perspektiv (Bergen, 2002), pp. 19-40. Ida Blom, "'Don't spit on the floor'. Changing a social norm in early twentieth-century Norway", in Hilde Sandvik, Kari Telste and Gunnar Thorvaldsen, eds., Pathways of the Past. Essays in Honour of Sølvi Sogner, (Oslo, 2002), pp. 231242. Ida Blom "'et Stykke ejendommeligt københavnsk Folkeliv?” Opplysningsstrategier i den danske kampen mot spyttevaner, c. 1900-1920", Tradisjon, 31:2 (2001), pp. 85-92. Ida Blom, "Voluntary Organisations fighting Tuberculosis c. 1900-c. 1940: A Norwegian-Danish Comparison" in Flurin Condreau and Michael Worboys, eds., Tuberculosis in National Context. (forthcoming Routledge).

3 Quoted from Anne-Lise Seip, Sosialhjelpstaten blir til. Norsk sosialpolitikk 1740-1920 (Oslo, 1984), p. 237-238. 
the population. Registration of cases as well as of deaths from TB was made mandatory. Medical treatment also became mandatory and occupations that involved producing or selling victuals or working as nannies or wet-nurses, were prohibited for the tubercular. Municipal authorities were authorised to inspect and disinfect, not only public premises but also private homes. For the better off this did not pose a big problem. In roomy homes with plenty of servants it was possible to take the precautions needed to limit contagion. This could be difficult for poor families. If contagion could not otherwise be avoided, patients might be compelled to move to a hospital or a home for tubercular. But married couples could not be separated and in order to further soften coercion state and municipality would pay for the treatment. Accepting such public assistance would not be seen as poor relief. The poor would therefore avoid the stigma and loss of civil rights that otherwise accompanied poor relief. ${ }^{4}$

The journal of the Danish Medical Association kept Danish physicians informed on Norwegian discussions on a law against TB and the laws enacted in Denmark in 1905 were very similar to the Norwegian law of 1900 . But in some respects the Danish laws were less restrictive. ${ }^{5}$ Coercive hospitalisation was not possible if this meant forcing a person to give up his or her occupation. It was feared that too strong prohibitions would weaken people's will to provide for themselves. But teachers and clerical persons who would be in contact with many people would loose their job if they caught tuberculosis. They would, however, be offered a small state pension. Also different from the Norwegian law, public economic support was offered to needy families of TB patients. As Signild Vallgårda has observed Danish TB legislation was coercive, but offered public assistance to the needy.

There were even fewer restrictions in Swedish TB legislation. ${ }^{7}$ The Swedish law of 1914 instructed physicians to report all deaths from TB, but contrary to in Norway and Denmark not all cases of the disease. Only patients who might represent an obvious danger of contagion should be reported. Registering the diseased was seen as stigmatising the patient and it was feared that ailing people might therefore

4 Terje Andreassen, Legene og tuberkulosen. Faser og forutsetnnger for tuberkuloseloven av 1900. Unprinted master thesis (Bergen, 1997), pp. 14-15. Ida Blom, Feberens ville rose. Tre omsorgssystemer $i$ tuberkulosearbeidet 1900-1940 (Bergen, 1998), pp.14 -15. Ida Blom, "Frivillige organisasjoner i kamp mot tuberkulose 1900-1940. En dansk-norsk sammenlikning" in Monika Jarnfelt ed., Den privat-offentliga gränsen. Det sociale arbetets strategier och aktörer i Norden 18601940. (Copenhagen, 1999), pp. 219-221. Aina Schiøtz, Folkets helse - landets styrke. 1850-2003. Det offentlig helsevesen i Norge 1603-2003, vol. 2. (Oslo, 2003), pp. 64-71.

5 Blom 1999, pp. 220-221. Christine Ebbesen, Tuberkulosebekampelse i Danmark 18751914. Unprinted master theses (Copenhagen, 1995), pp. 52-73. Signild Vallgårda, Folkesundhed som politikk. Danmark og Sverige fra 1930 til i dag (Aarhus, 2003), pp. 100-102.

6 Vallgårda 2003, p. 111

7. Jenny Björkman, Vård för sambällets bästa. Debatten om tvångsvård i svensk lagstiftning 1850-1970 (Stockholm, 2001), pp. 140-144 Vallgårda 2003, pp. 102-110. 
avoid seeing a physician. Public inspection of private homes was never accepted. Treatment was not made mandatory, but publicly funded treatment was offered without the stigma of poor relief. Like in the other Scandinavian countries, tubercular persons were prohibited from working with milk and as wet-nurses. While the Danish law opened for state support to run TB institutions, the Swedish 1914 law offered public support only for dispensaries that should spread information and support the sick. ${ }^{8}$

A new law replaced the 1914 law in 1939. After long discussions, Swedish legislators now accepted that all cases of TB had to be reported and mandatory examination was made possible even by police assistance but treatment remained voluntary and consequently mandatory hospitalisation was never accepted. This was considered an unacceptable infringement on civil liberties. Swedish politicians argued that since tuberculosis was a long-lasting disease, coercion would have more serious consequences with $\mathrm{TB}$ patients than with people suffering from other contagious diseases. However, following the law on child care (barnavårdslagen), children could be forcibly removed from a tubercular home. Such precautions were not understood as coercion, but as protection of the weak. The main course of action in Sweden was information and preventive measures.

On the other hand, little economic assistance was offered to tubercular patients. Economic considerations were at work when decisions were made on compulsory measures. Mandatory treatment would necessitate construction of a great number of sanatoria, and public support for the families of patients who were hospitalised against their will would be a heavy burden for public finances. So would compensation to people who would be forbidden to work in certain trades because they suffered from TB. ${ }^{\text {' }}$

In all three Scandinavian countries the course of action legislated to protect the healthy against TB also contained some assistance to cure the sick. Most discussed was public financing of mandatory treatment and in Denmark economic assistance to the family of the diseased. Another approach simultaneously seeking to change unwanted behaviour and to assist the sick did not surface in legislation. Still, it should shortly be mentioned as a reminder of the complicated picture of antituberculosis efforts.

\section{Information Campaigns}

Extensive information campaigns were organized not least by voluntary organisations such as the National Anti-Tuberculosis Organisations. Informing people of

8. Bjørkman 2001, pp. 145-154. Vallgårda 2003, p. 102.

9 Bjørkman 2001, pp. 152-154. Vallgårda 2003, pp.102-107. 
how the disease spread and of what to do to minimise the danger of transmission meant appealing to the responsible and persuading or frightening the irresponsible to act according to certain rules. Information aimed to change unacceptable behaviour and mobilise individual responsibility in the fight against disease. ${ }^{10} \mathrm{In}$ this respect Swedish authorities made a monumental effort through the activities of hundreds of dispensaries. In Norway and Denmark intensive lecturing campaigns and distribution of leaflets with advice against TB were part of this activity and nurses visited tubercular homes to inform and assist people in fighting the disease. In all three countries sanatoria were not only seen as treatment institutions, but also as offering the opportunity of educating the sick and hopefully have them spread knowledge of how to combat TB when they returned to their homes.

Both in information campaigns and in legislation, the poor and irresponsible were the main target groups. They were understood as the most important carriers and in need of information and education. People living in roomy and prosperous homes would not be submitted to the coercion applied to the poor. They were supposed to understand how to behave and be able to adopt the needed precautions without interference from public authorities.

\section{National Differences}

As we have seen there were some differences in the overall similar pattern in Scandinavian TB legislation. Why was this so? Extensive comparative studies would be needed to indicate safe answers to this question, but some explanations may be suggested.

The Norwegian law was the most coercive, Denmark followed with a little less coercion while Sweden legislated even fewer mandatory measures. Could the threat from TB be perceived as more serious in one country than in another? Literature treating discussions in the Scandinavian parliaments gives no indication that legislators evaluated the dangers of TB differently in the three countries. Still, a glance at national mortality rates from TB may suggest a difference. Around 1900 deaths from TB reached a climax in Norway with 299 deaths from tuberculosis of the lungs per 100.000 inhabitants for men, 319 for women. ${ }^{11}$ Something drastic seemed to be required to stop the disease and the Norwegian law was the most restrictive. Death rates from TB declined from 1900, but remained higher in Norway than in

10 Blom 2001. Blom 2002. Björkman 2001, pp. 149. Vallgårda 2003, pp. 107-110. Teemu Sakari Ryymin, 'Formaningens former i et flerspråklig område. Propaganda i antituberkulosearbeidet i Finnmark.' in Kirsti Malterud og Kari Tove Elvbakken, Rapport fra seminaret Sunnhet og sykdom i kulturelt perspektiv, pp. 2005, 63-72. In print.

11 Mortality from tuberculosis 1896-1965. Historical Statistics 1968, Central Bureau of Statistics, (Oslo, 1968) Table 43, p. 64. 
the other Scandinavian countries all through the period. Although statistics for Denmark are uncertain, there are indications that a reduction had already started in the major cities during the 1880s. A reduction in deaths from TB had also taken place in Sweden in 1914. ${ }^{12}$ Where TB took fewer lives, less coercion might be seen as sufficient. Between 1900 and 1940 death from TB was seriously reduced, but rates remained higher in Sweden than in Denmark. The slightly more restrictive measures introduced in Sweden in 1939 may in part be explained as a consequence of this situation, but an absence of legislation in other countries with high death rates from TB shows that there is not necessarily a direct link between death rates and legislation. ${ }^{13}$

It seems that the political situation may also help understand the difference between Sweden on the one hand, Denmark and Norway on the other. Norwegian and Danish Social Democrats argued that it was not irresponsibility, but low wages and poor living conditions that made the working class the worst carriers of TB, but around 1900 when the Norwegian and Danish laws were enacted, Social Democrats were still a minority in the two parliaments. In 1914 when the Swedish law was accepted the newly adopted general suffrage for men, a quickly growing Social Democratic party and the recent adoption of parliamentarism may have made it less acceptable to submit the poor population to special constraints. ${ }^{14}$

Further, medical perceptions of the infectious character of TB may have had some impact. The discovery of the tuberculosis bacillus did not immediately convince physicians of the contagious character of the disease, but around 1900 there was agreement that the living conditions of the poor eased transmission of the disease. ${ }^{15}$ Still, throughout the first decades of the twentieth century, Swedish physicians disagreed on the contagiousness of TB. ${ }^{16}$ Some maintained that the most important provision would be to be careful when coughing and that mandatory treatment was to overdo precautions. Without denying social differences in trans-

12 Blom 1999, p. 211. Vallgårda 2003, p. 101.

13 Broadening comparison to include Finland - impossible in this paper-would probably be helpful for a discussion of how to explain different approaches. In Finland discussions around 1900 did not result in a law on TB despite the fact that TB was the most important single cause of death. It was not until 1927 that a law resembling the Norwegian law was enacted. I am grateful to Teemu Sakari Ryymin for this information, which is build on Maria Lähteenmäki, "En sjukdomsdrabbad familj i nord", Historisk Tidskrift för Finland, vol 89, 3 (2004), pp.193-209. Hanna Kuusi, "Tuberkuloosin torjunta ja moderni kansalainen" in Helen Ilpo and Hauho Mikko eds., Kansalaisuus ja kansanlerveys (Helsinki, 2003), pp. 33-57. "Om tuberkulosearbeidet i Finland", Meddelelser fra Den norske nationalforening mot tuberkulosen, 1928, vol. 18, nr. 87 (1928), pp. 45-48.

14 Political circumstances may have been important also for Finland. The difficult relations to Russia until 1917 and the civil war after independence may explain why TB legislation may have had to wait.

15 Ebbesen 1995, pp. 44-48. Andreassen 1997, pp. 102-103.

16 Bjørkman 2001, pp. 141-144 
mission, in 1931 Sweden's main physician for TB advanced yet another explanation for the spread of the disease, the theory of natural biological immunisation of the population. It was observed that death rates from $\mathrm{TB}$ fell earlier in the southern part of Sweden while it was still rising in the northern districts. The explanation forwarded was that when TB had raged for some time in a given population, people developed a growing power of resistance to infection and the disease subsided. ${ }^{17}$ In this light, costly public policies to combat the disease were less important. TB would extinct itself through biological changes in the human body. This argument was not found in the Norwegian and Danish discussions, although the same pattern could be observed in the spread of TB in Norway as in Sweden. ${ }^{18}$ Divergent opinions on how TB was spread may be one more reason why Sweden followed a somewhat different path from the other two Scandinavian countries, when legislating on this disease.

Since TB was far more life threatening and widespread than VD, it might be expected that behaviour seen as causing TB was met with stricter provisions and more coercion than those adopted to fight VD. But this was not the case. On the contrary, fighting venereal diseases opened for much more coercion.

\section{Legislating on Venereal Diseases}

While in the case of TB coercive measures were directed at a broad group of individuals, where VD was concerned the target group was narrow. The danger of contagion was seen as almost entirely coming from the prostitutes. Perceptions of acceptable sexual behaviour strongly condemned prostitution. It was thought that for both men and women, sexual intercourse ought to be strictly limited to married life, but there was a widespread belief that men's sexual urges were so strong that it was very difficult for men to limit themselves to marital sex. Consequently, prostitution was seen as a necessary evil and throughout the nineteenth century, police

17 Dr. Ostenfeld, Dr. Heitmann and Dr. Neander, Tuberculosis in Denmark, Norway and Sweden, League of Nations Health Organisation. (Geneva, 1931), p. 115. See for a similar pattern in Europe Greta Jones, 'Captain of all these men of death'. The History of Tuberculosis in Nineteenth and Twentieth Century Ireland, (Amsterdam/New York, 2001), pp. 1-2. The pattern of the spread of TB in Europe may seem to confirm this theory. Death rates from TB declined in England and Wales around 1870, in France and Germany towards the end of the nineteenth century, while it was still rising in Ireland and Norway. In these countries the reduction did not start until after 1900. Harrison 2004, p. 128.

18 Per Arne Hestetun, Velferdsekspansjon og organisassjonsendring. Ei analyse av frivillige organisasjonar si rolle $i$ arbeidet mot tuberkulosen. Unprinted master theses, (Bergen 1985), p. 54. Blom 1998, pp.10, 12. 
control with prostitutes was the main provision against the spread of these diseases. $^{19}$

This policy was changed during the late nineteenth and early twentieth century. The Danish parliament in 1874, 1895, 1901 and especially in 1906 and 1947 legislated on the problem of VD. The Swedish Lex Veneris of 1918 introduced procedures very similar to those legislated in Denmark, while it was not until 1947 that a national Norwegian law regulated the fight against VD. Until then, municipal bylaws regulated approaches to VD.

\section{Danish and Swedish Legislation 1874 to 1947}

Danish legislation already in 1874 introduced provisions that would later characterize Scandinavian VD legislation, i.e. mandatory and free treatment of all infected citizens. ${ }^{20}$ The condition was that they consulted a public physician. In 1895 the demand that prostitutes should live in a brothel was abolished and in 1901 brothels were prohibited. This change in attitudes to control of prostitutes were seen as the result of the efforts of the Association against the Statutory Protection of Immorality, founded in 1879 as a Danish branch of 'La Federation britanique, continentale et generale pour l'abolition de la prostution legale', and with a considerable number of women in influencial positions. ${ }^{21}$

In 1906 the Danish parliament enacted a law that widened provisions so far mainly applied to prostitutes to include the whole population. Medical control, at

19 For Norway, Aina Schiøtz, "Prostitusjon og prostituerte i 1880-åras Kristiania" and Kari Melbye, "Prostitusjon og kontroll" in Anne-Marit Gotaas, Brita Gulli, Kari Melby and Aina Schiøtz, Det kriminelle kjønn (Oslo, 1988), pp. 35-39 and pp.83-85. For Denmark, Karin Lützen, Byen temmes: karnefamilie, sociale reformer og velgørenhed $i$ 1800-tallets København ( Copenhagen, 1998), pp.219-285. For Sweden, Yvonne Svanstrøm, Policing Public Women. The Regulation of Prostitution in Stockholm 1812-1880 (Stockholm, 2000), pp. 82-86. An early analysis of this discussion in Scandinavia is Elias Bredsdorff, Den store nordiske krig om seksualmoralen. (Copenhagen, 1973). For similar attitudes outside Scandinavia, see Judith Walkowitz, Prostitution and Victorian Society: Women, Class, and the State (Cambridge, 1980). Mary Spongberg, Feminizing Venereal Disease: The Body of the Prostitute in Nineteenth-Century Medical Discourse (Basingstoke, 1997). Lutz Sauerteig, Krankheit, Sexualität, Gesellschaft. Geschlechtskrankheiten und Gesundheitspolitik in Deutschland im 19. und frühen 20. Jahrhundert (Stuttgart, 1999), pp. 57-62 and $89-125$.

20 The Danish government already in 1790 issued a decree allowing free treatment of VD for 'the common people'. See Ida Blom, "From Regulationism to the Scandinavian Sonderweg legislating to prevent venereal diseases in Denmark during long the $19^{\text {th }}$ century", Continuity and Change, 20/2 (2005), pp. 265-286.

21 For more information on Danish legislation before 1906, see Lützen 1998, pp. 219246, Merete Bøge Pedersen, Den reglementerede prostitution $i$ København 1874-1906, (Copenhagen, 2000) and Merete Bøge Pedersen, Prostitutionen og Grundloven. Unprinted ph.d.thesis (Copenhagen, 2003). See also Blom 2005. 
times assisted by the police, was accepted for any person who could not prove that he or she earned their living in a lawful manner. Resistance might result in prison or forced labour. This paragraph referred to the law on vagrancy and MPs openly admitted that despite gender neutral formulations the paragraph targeted prostitutes. The small group of Labour MPs and a few Radical Liberals strongly objected to such a course of action, characterising it as a class law with a gender bias. They argued that '...the Woman does not seem to be more culpable than the Man who buys her body. ${ }^{22}$ Consequently, the male customer should also be punished. But the supporters of the law argued that it was not fornication as such that was condemned. But 'when this becomes public, when this reveals itself in a way liable to harm the public, society has both a right and a duty to defend itself." ${ }^{23}$ The opposition was defeated, the paragraph was accepted and no special provisions were made for customers of prostitutes.

Thus, coercion targeting a morally deviant group of women continued to be an important means to attempt to limit VD. Different from where TB was concerned, poverty alone did not suffice to stigmatise the diseased. Despite the fact that both men and women broke the code of sexual morality and that many more men than women suffered from VD, prostitutes continued to be seen as the main carriers.

Also for other citizens, VD was considered a stigmatising disease. If a VD patient did not follow medical instructions, the physician was to report the patient to the police and he or she would be brought in for medical examination and treatment. A minority of Danish MPs criticised such coercion. It would continue to make VD a shameful disease, and might tempt patients to keep their disease a secret as long as possible. Consequently, free and easy access to medical assistance would be a much better way of combating VD. ${ }^{24}$

Also in this case, the minority lost its cause. Suffering from VD was seen as a sign of indecent behaviour. Coercion of all recalcitrant patients was needed to fight these diseases, but prostitutes were singled out for special control.

A very similar law was enacted in Sweden in 1918. The Lex Veneris, as the law was called, also broadened coercion to include all citizens. Police control with prostitutes continued, like in Denmark now legitimised through the law on vagrancy. The main difference between the Swedish and the Danish law was that the Swedish law made it mandatory for physicians to trace sources of infection. ${ }^{25}$

22 Holger Rørdam, MP for the Liberal Reform Party. Blom 2005, p. 275.

23 Kristian Bjerre, MP from the Agrarian Party. Blom 2005, p. 275.

24 This course of action was accepted in Britain. France and Italy continued to use the control of prostitutes as the main means in the fight against VD, while Germany from 1927 followed a policy similar to that of the Scandinavian countries. See Roger Davidson and Leslie Hall eds., Sex, Sin and Suffering. Venereal disease and European Society since 1870, (London and New York, 2001) for a broad presentation of VD policies in Europe.

25 Anna Lundberg," 'Passing the 'Black Judgment': Swedish social policy on venereal disease in the early twentieth century" in Davidson and Hall 2001, pp. 29-43. Ida Blom, 
This expedient was not integrated in the Danish law until 1947, when a new law replaced the 1906 law. The titles of the two Danish laws indicate a change in the approach to VD. While the 1906 law had been called a "Law to Prevent Public Impropriety and Venereal Disease", the law enacted in 1947 was called "Law on Prevention of Venereal Disease" and it was expressly stated that the 1947 law was a law on epidemics. ${ }^{26}$ A number of legislative changes during the 1930 s had made a new law necessary. Among other things, all paragraphs targeting prostitutes had been removed and placed in the penal code. Consequently, the 1947 law was more consistently phrased in gender neutral language.

An important reason for the new law was the recent observation that contrary to what had usually been the case, during the war period VD had become almost as frequent with women as with men. This was seen as presenting a serious threat, and now not only prostitutes, but also young women frequenting dance halls were seen as carriers of infection. ${ }^{27}$ When the parliamentary discussion touched on innocent victims, such as married women who contracted the disease from frivolous husbands, it became clear that husbands were protected. The penal code made it an offence, liable to imprisonment, to consciously infect someone else. When this happened within a family setting prosecution was only possible if the victim reported the case. Almost no wives who had contracted VD from their husbands would do so. The Danish Women's Society (Dansk Kvindesamfund) in vain attempted to make it possible to prosecute husbands also in cases where wives did not demand prosecution. Protecting marriage seemed more important than targeting a male carrier. ${ }^{28}$

An important new clause tightened coercion. Contact tracing now became mandatory and police assistance could be called in to make the search efficient. In most respects, then, by 1947 legislation on VD in Denmark and Sweden followed the same course of action.

"Fighting Venereal Diseases: Scandinavian Legislation c. 1800-c. 1950". Journal of Medical History, Spring 2006b, pp.209-234.

26 Blom 2006b.

27 Ida Blom, "From Cocercive Policies to Voluntary Initiatives. Legislating to Prevent Venereal Diseases in Denmark during the $20^{\text {th }}$ Century." The Scandinavian Journal of History. Forthcoming 2008.

28 Danish women had won national suffrage in 1915, but women MPs were in 1947 still a very small minority. They tried to bring problems of special importance to women into the parliamentary debates but they had no impact on the final results. Blom $2006 \mathrm{~b}$. 


\section{Norway - A Slow Learner?}

The Norwegian parliament did not legislate on VD until 1947. When this finally happened, it adopted the same principles as those presented in Danish and Swedish legislation.

This did not mean that VD was a neglected disease in Norway. Until 1947 municipal by-laws took care of provisions against VD. In Kristiania, the Norwegian capital, brothels were closed in 1887 and from 1888 provisions were introduced that were very similar to those legislated later in Denmark and Sweden: mandatory treatment of all VD patients, at times assured through police assistance. ${ }^{29}$ But municipal by-laws varied from one municipality to another. ${ }^{30}$ In some municipalities contagious VD patients were offered free treatment, elsewhere everybody had to pay. Free treatment of all VD patients was not the rule until a national law on VD was enacted in 1947. Like in the two other Scandinavian countries, prostitutes continued to be seen as the main target. Where the law on VD did not suffice, other legislation, the penal code and the law on vagrancy, made prostitution in public areas a criminal offence. ${ }^{31}$

Why did Norway legislate so much later on VD than Denmark and Sweden? Late industrialisation and less urbanisation may have made the problem less pressing in Norway than in the other two Scandinavian countries. However, the main explanation seems to be economic problems. A number of attempts at legislating for the whole country were made already during the 1890s. A bill very similar to the Swedish law of 1918 was suggested in 1923, but withdrawn for economic reasons. ${ }^{32}$ At that time also provisions to combat TB were sometimes curtailed in order to not burden public finances. ${ }^{33}$ Finally, opinions on how to combat VD still in 1947 varied greatly from one region of the country to another. This may have been a reason for leaving provisions to be adopted by local municipal by-laws instead of fighting for a national law where compromises might be difficult to obtain. ${ }^{34}$

29 The name of the Norwegian capital was changed to Oslo in 1925.

30 Studies of municipal arrangements have only been made for Oslo and Bergen. For Oslo see Schiøtz 1988 and Ida Blom, "Fra tvang til frivillighet? - Forebygging av veneriske sykdommer i Kristiania, 1888-1910" in Benum et al., eds., 2003, pp.125-140. For Bergen see E. Koren, "En Trusel for selve Samfundene." Venerisk sykdom: tiltak, medisinsk forståelse og moraldebatt $i$ Norge 1880-1927. Unpublished master's thesis. (Bergen 2003), 68-71, and Christopher John Harris, "Kontroll av prostituerte i Bergen" in Kari Tove Elvbakken and Grete Riise eds., Byen og helsearbeidet (Bergen, 2003), pp. 157-174.

31 Melbye 1988, pp. 112-116.

32 Koren 2003, pp. 50-55.

33 Anne-Lise Seip, Veiene til velferdsstaten. Norsk sosialpolitikk 1920-1975. (Oslo, 1994), pp. 101-102.

34 Koren 2003, pp. 57-58. Blom 2006b. 
What finally sparked off a national law on VD in 1947 was the rise of reported cases during the Second World War. During and right after the German occupation special attention was paid to tracing women who suffered from VD. A provisional edict in 1945 allowed arresting women and placing them in camps on the suspicion that they might suffer from VD and consequently might spread the diseases. Consequently, reported cases of VD for the first and only time were much higher for women than for men. This raised fear that 'all these women' would spread VD among the male population. ${ }^{35}$ A national law was meant to avoid this danger.

In all three Scandinavian countries all citizens were subjected to strict public control in order to limit contagion with VD. To suffer from VD continued to be seen as a sign of unacceptable sexual behaviour. But prostitutes, and during the interwar and postwar years a broader section of young women, were seen as the main sources of infection and special provisions were applied to control them.

\section{Summing up}

During the first half of the twentieth century, Scandinavian legislation to combat $\mathrm{TB}$ and VD bore the imprint of the coming welfare states. According to the letter of the laws all citizens were to be treated in the same way and submitted to the same kind of coercion, but a closer look reveals that certain groups were seen as more prone to spread disease than others, and consequently submitted to stricter control. This was met with broad acceptance. Few disputed the idea that the state had a responsibility to protect society against carriers of disease. There were few objections to policies that made it unavoidable to infringe on the civil liberties of diseased persons who could not - or would not - on their own take care not to spread the disease.

Concerning the timing of the laws, slightly different political circumstances as well as varying understandings of how the diseases were spread probably may help explain nuances in Scandinavian TB-legislation, while economic differences, variations in urbanisation and industrialisation as well as regional varieties could be seen as a reason for a later national legislation on VD in Norway than in Denmark and Sweden. No doubt, however, further comparative research is needed to fully understand the differences among the Scandinavian countries.

Cultural perceptions of accepted behaviour influenced the definition of who belonged to the groups of individuals that would have to be controlled as well as the kind of coercion applied to control them. There was no disagreement among

35 Ida Blom, "Krig og kjønnssykdom-Norge 1945-1953" in Göran Fredriksson m.fl. (red.), Könsmaktens förvandlingar. En vänbok till Anita Göransson. Skrifter från Institutionen för Arbetsvetenskap, (Göteborg, 2003), pp. 13-31. 
Scandinavian lawmakers as to whom these groups were. In the case of TB class differences between lawmakers and carriers of infection were often pronounced. Where VD was concerned gender came in as a further marker of differences and opened for even stricter provisions.

TB legislation expressed the understanding that lack of cleanliness, the habit of spitting and irresponsibility was seen as unacceptable behaviour, prevalent with poor people. Such behaviour led to coercive measures. Sexual immorality was seen causing VD and much harder condemned, despite the fact that VD was much less dangerous and occurred much less often than TB. Consequently, cultural understandings of gender and sexuality made $\mathrm{VD}$ an even more stigmatising disease than TB. Gender neutral formulations of VD legislation did not conceal that VD policies continued to target women, especially prostitutes and young women, and coercion was stronger towards those who suffered from VD than towards TB patients.

Ida Blom is professor emeritus at the Department of History, University of Bergen, Norway. 